\title{
Environmental Aspects of Sustainable Economic Growth in the ASEAN Area
}

\author{
Nikolaev Andrey Mikhailovich \\ Saidmukhtorov Alisherjon Abdukhalikovich \\ Department of International Law, RUDN University, \\ Moscow, Russia
}

\begin{abstract}
In this article, authors review to what degree ASEAN's integration agenda reflects ecological aspects of the economic growth of the member states. The authors, guided by the provisions of the concept of sustainable development, conduct an analysis of the implementation in the ASEAN treaty practice of the principles of the final document of the UN Conference on Sustainable Development held from June 20 to 22, 2012 in Rio de Janeiro.
\end{abstract}

Keywords-Sustainable development concept; Environmental safety; Economic cooperation; ASEAN; Integration; International treaties

\section{INTRODUCTION}

With limited resources available to meet the growing consumption of the Earth's population, a large number of states continue the practice of sacrificing the environmental aspects of functioning of their national economic actors. Such states, mostly represented by a group of states with developing type of economy and driven by the desire to protect their production capacities mainly comprised of "obsolete" technology, explain their extremely modest success in promoting the commitment to the "modern" concept of environmental security by the lack of capital needed for the ubiquitous and comprehensive development of green technologies, the limitedness of their territories in combination with demographic problems and insufficiency of resources. A number of experts explain the lack of attention to environmental protection by some states by the desire of these states to reduce the costs of this category [1].

\section{CORRELATION OF THE ENVIRONMENTAL SECURITY MATTERS}

When discussing the mechanisms for regulating environmental issues at global level, it is worth starting with the commitment to global security proclaimed by the international community of states when establishing the United Nations. Thus, Art. 1 of the UN Charter states that one of the most important goals of this organization is the maintenance of international peace and security and the adoption for this purpose of effective collective measures to prevent and eliminate threats to peace and suppress acts of aggression or other violations of peace and the exercise by peaceful means, in accordance with the principles of justice and international law, settling or resolving international disputes or situations that could lead to a breach of the peace. Having made a reservation that no strict definition of "international security" exist in Russian international law science, it seems reasonable to refer to the existence of various clusters, which together constitute the "international security" category that is protected by the international community of nations.

In support of this statement, one can refer to the work of such scientists as V.E. Zhivarev, who believe that the norms and principles of the international security law are aimed, inter alia, at ensuring the political, military, economic, food, environmental and information security of states and the stability of international relations [2]

The interdependence of the world countries in the matters of ensuring all aspects of international security in the enumeration of the principles of international security law is also cited by S.A. Malinin [3].

The direct correlation of the global and environmental security problems of the entire world community has also been emphasized by A. Kh. Abashidze, A.M. Solntsev and F.I. Sotnikov [4].

One of the notable areas of the policy pursued by the international community of nations in ensuring universal environmental security is to consider the issues of ensuring environmental protection in the context of ensuring the processes of sustainable growth of all states in the world in general, and states with developing or transitional economies in particular.

In support of this statement, I would like to dwell further on the example of the Association of Southeast Asian Nations (ASEAN), which, in accordance with the classification of existing levels of international security adopted in the international law science, is a regional mechanism for ensuring and regulating security issues in general, and environmental issues, in particular.

\section{ENVIRONMENTAL AGENDA IN ASEAN REGION}

When viewing this organization in the context of an institutional mechanism for ensuring international security in the South-East Asian region, it is worth pointing out the obvious economic focus of the association. This, in turn, determined the ASEAN countries' stated goal in the text of the Cebu Declaration on Accelerating the Establishment of the ASEAN Community by 2015, a policy for achieving synergy of all the activities of the organization around the following three pillars of the association: the ASEAN Security Community, The ASEAN Economic Community and the ASEAN Socio-Cultural Community. 
By conditional delineation of the range of issues considered within a particular community in the context of sustainable development concept, ASEAN conducts a direct line between the promotion of economic cooperation among the states of the association, the environmental aspects of such cooperation and the social welfare of the peoples inhabiting the ASEAN area arising from those two aspects.

It is noteworthy that in such a practice of combining the issues of economic growth, social well-being and security, ASEAN follows the example of a wider community of nations reflected at the global level in the text of the final document of the United Nations Conference on Sustainable Development held on June 20 to 22, 2012 in Rio de Janeiro (Brazil) and called "The Future We Want". In particular, paragraph 6 of this document places sustainable development in dependence on progress in issues of sustainable and inclusive economic growth, social development and environmental protection [5].

History shows that the states located in the ASEAN region have come a long way towards achieving the current level of social development and economic well-being. At the same time, observations also indicate that progress has taken place with varying success and has not always corresponded to the current concept of sustainable development. That is why the maintenance of carefully developed and constantly improving mechanisms for sustainable development remains relevant for the member states of this association.

The awareness of the member states of the need for continuous improvement of the mechanisms for regulating the issues of economic development, security and social wellbeing can be clearly seen in their practice within ASEAN.

Thus, the issues of environmental protection in the implementation of measures to stimulate economic activity in the ASEAN area are reflected in various documents of ASEAN.

One of the most notable in this series of documents is the ASEAN Agreement on Transboundary Haze Pollution (AATHP), which obliges the member states of the association to mitigate, through joint concerted efforts, the effects of transboundary pollution arising from land and/or forest fires [6].

This agreement was signed in 2002 and was based on the previous practice of regulation the environmental issues. In this regard, it is appropriate to list the documents preceding the signing of the ASEAN Agreement on Transboundary Smoke Pollution and the establishment of ASEAN communities aimed at addressing environmental security issues: [7];

- Manila Declaration on the ASEAN Environment, 1981

- Bangkok Declaration on the ASEAN Environment, 1984 [8];

- ASEAN Declaration on Heritage Parks and Reserves, 1984 [9];

- Agreement on the Conservation of Nature and Natural Resources, 1985 [10]; [11];

- Jakarta Resolution on Sustainable Development, 1985

- The Kuala Lumpur Accord on Environment and Development, 1990 [12];

- Singapore Resolution on Environment and Development, 1992 [13];

- Bandar Seri Begawan Resolution on Environment and Development, 1994 [14];

- Jakarta Declaration on Environment and Development, 1994 [15].

When listing the documents reflecting the high degree of conjugation in the ASEAN practice of economic growth, environmental safety and social well-being issues, it is worthwhile to dwell in more detail on the content of some of them.

For instance, in the preamble of the Agreement on the Conservation of Nature and Natural Resources, ASEAN member states recognize the dependence of sustainable socioeconomic development on the preservation of the environment. It also recognizes the interdependence of living resources and natural resources as parts of a single ecosystem.

Article 2 of this agreement obliges the states to put the issues of environmental protection on a par with the issues of ensuring economic growth and social well-being of their citizens when developing their national regulatory and legal acts.

The Jakarta Resolution on Sustainable Development determines the need to combine the efforts of states, private companies, non-state associations, educational and academic organizations in solving the problems affecting the general well-being of the ASEAN peoples, including but not limited to the problems of:

- sea;

- land recourses and land contamination;

- impact of tropical rains;

- air cleanness;

- urban and rural pollution.

In the preamble of the Singapore Resolution on Environment and Development, ASEAN member States stress the importance of integrating environmental aspects into sustainable development, and in this regard, the importance of implementing various programs aimed at supporting the global environmental management and the accompanying sustainable development, as declared at the UN Conference on Environment and Development held in Rio de Janeiro in 1992.

Finally, in the Jakarta Declaration on Environment and Development, ASEAN member states have further put the development of economic activities in the member states of the association in dependence on environmental factors.

In article 1 of the Declaration, the ASEAN member states agreed to support further development of the member state 
economies on the basis of environmental efficiency and expediency principles.

Article 2 of the Declaration expresses the agreed will of the member states of the association to produce, use and export goods and services produced on a resource-saving basis.

Article 10 calls on developed countries to fulfill their commitments to provide additional resources and transfer of technologies referred to in Agenda 21, which was also adopted at the United Nations Conference on Environment and Development held in Rio de Janeiro in 1992.

The listed sources for achieving the goals of sustainable development are reinforced in subsequent practice of the ASEAN member states through guidelines and programs ensuring the practical implementation of the agreements stated and endorsed in the documents listed above.

Within the framework of measures aimed at minimizing the negative impacts of the agricultural sector, ASEAN member states have developed the General Guidelines for Conducting Controlled Burning Practices. The main objective of this manual is to ensure that the states unite the uniform and most environmentally friendly practices of conducting controlled burning of crops, crop residues in fields and forests.

The next in this series of practical initiatives is the ASEAN Strategic Action Plan for Water Resource Management (ASEAN). This plan provides guidance for integrated water resources management in the ASEAN area, as well as a set of strategies for addressing the most frequently encountered issues and problems in water management.

As part of the ASEAN Peatland Management Strategy for 2006-2020 and the ASEAN Programme on Sustainable Management of Peatland Ecosystems 2014-2020, member states were provided with an action plan for the sustainable management of peatlands, reduction of fires and implementing the provisions of the ASEAN Agreement on Transboundary Haze Pollution.

\section{CONCLUSION}

Summarizing the aspects of all the above-mentioned achievements of ASEAN on the way to ensuring the environmental security carried out by the states of this association through the prism of the sustainable development concept, it is worth emphasizing the importance of further supporting the policy of strengthening and developing the foundations and mechanisms for regulating the economic and environmental aspects of the welfare of the association's member states. It is difficult to overestimate the importance of further joint work of the association's states in developing and practical implementation of effective mechanisms to stimulate investments in "green" technologies in the ASEAN area. Such mechanisms should continue to integrate environmental aspects into the tools of economic growth. They should also promote the harmonization of the national level policies for stimulating economic growth at the regional level. All this in aggregate will contribute to strengthening of the ASEAN Economic Community and the prospects for the increased well-being of the peoples living in the ASEAN region.

\section{REFERENCES}

[1] Boklan D.S. Vzaimodeystvie mezhdunarodnogo ekologicheskogo i mezhdunarodnogo ekonomicheskogo prava: thesis for a doctor's degree. Moscow, 2016. P.5.

[2] Mezhdunarodnoe pravo: Lecture notes / MIEMP; Compiled by .. Zhivarev V.E. - M., 2004, P. 68

[3] Pravo mezhdunarodnoy bezopasnosti // The course of international law: in 7t. Malinin S.A. M., 1989. T.4.P.167-171

[4] Mezhdunarodnoe ekologicheskoe parvo: Collection of documents. Issue 1. Basic UN documents. Abashidze A.Kh., Solntsev AM, Sotnikov F.I. M .: RUDN, 2008,P. 9

[5] The Future We Want: Outcome document of the United Nations Conference on Sustainable Development Rio de Janeiro, Brazil, (2012). Retrieved on June 1, 2018, from https://sustainabledevelopment.un.org/content/documen ts/733FutureWeWant.pdf

[6] ASEAN Agreement on Transboundary Haze Pollution, (2002). Retrieved on June 1, 2018, from http://haze.asean.org/?wpfb_dl=32

[7] Manila Declaration on the ASEAN Environment, (1981). Retrieved on June 1, 2018, from http://environment.asean.org/manila-declaration-onthe- asean-environment/

[8] Bangkok Declaration on the ASEAN Environment, (1984). Retrieved on June 1, 2018, from http://environment.asean.org/bangkok-declaration-on- the-aseanenvironment/

[9] ASEAN Declaration on Heritage Parks and Reserves, (1984). Retrieved on June 1, 2018, from https://environment.asean.org/asean-declaration-on- heritage-parks-andreserves/

[10] Agreement on the Conservation of Nature and Natural Resources, (1985). Retrieved on June 1, 2018, from https://environment.asean.org/agreement-on-the- conservation-ofnature-and-natural-resources/

[11] Jakarta Resolution on Sustainable Development, (1985). Retrieved $\begin{array}{cccc}\text { on } \quad \text { June } 1, & 2018, \quad \text { from } & \\ \text { http://environment.asean.org/jakarta-resolution-on- } & \text { sustainable- }\end{array}$ development/

[12] The Kuala Lumpur Accord on Environment and Development, (1990). Retrieved on June 1, 2018, from https://environment.asean.org/thekuala-lumpur-accord- on-environment-and-development-issued-by-theasean- ministers-for-the-environment-at-the-fourth-asean- ministers-forthe-environment-meeting/

[13] Singapore Resolutionon Environment and Development, (1992). Retrieved on June 1, 2018 from https://environment.asean.org/resolution-on- environment-anddevelopment-2/

[14] Bandar Seri Begawan Resolution on Environment and Development, (1994). Retrieved on June 1, 2018 fromhttp://arcagreement.asean.org/file/doc/2015/01/bandar- seri-begawan-resolutionon-environment-and- development.pdf

[15] Jakarta Declaration on Environment and Development, (1994). Retrieved on June 1, 2018 from http://environment.asean.org/jakarta-declaration-on- environment-anddevelopment/ 